\title{
Determinants of Profitability in Life and Non-Life Insurance Sector of Pakistan: An Endogenous and Exogenous Evaluation
}

\author{
Shams Ur Rahman \\ Muhammad Farooq Jan ${ }^{2}$ \\ Khursheed Iqbal ${ }^{3}$
}

\begin{abstract}
The study is designed to identify the determinants of profitability in the insurance industry of Pakistan. The panel data set of 41 insurance companies (life, non-life, and takaful insurance) from 2007-2017 was employed. Hausman's specification and Breusch-Pagan Lagrange multiplier (LM) tests have selected the most appropriate test i.e. fixed effect and pooled OLS model for this study. The results of pooled OLS and fixed effect model reveal that insurance specific and macroeconomic factor like leverage, business risk, and inflation rate are negative but significantly affect the profitability of the insurance sector. However, size and GDP rate has a positive and statistically significant influence on profitability. Liquidity and growth are insignificant determinants of the study. This is the first study that covers the entire insurance industry, which is also composed of the takaful industry, along with firm-specific and country-specific attributes and applies the most suitable models for the study. Thus, this study is very important for top-echelon and policy-makers of the insurance sector of Pakistan regarding the profitability of the firm and wealth of the shareholders.
\end{abstract}

JEL Classification: G20, G22, G23.

Keywords: profitability, Determinants, insurance companies, firm level, macroeconomic, fixed effect, pooled OLS, Pakistan

\section{INTRODUCTION}

The major function of a financial system is to grease the machinery assisting the economic operation of a country. Therefore, financial institutions also play a central role in economic development of a country by providing valuable services in money and capital market. The main concern of any firm is to carry out best performance by maximizing shareholder wealth (Gitman, 2007 and Ocampo, 2018). Moreover, firms meet the needs of internal and external stakeholders by developing competitive strategies and enhancing market shares. More purposely, insurance companies enhance financial stability, facilitate trade, commerce, capital arrangements and mobilize savings (Skipper, H. D, 1997). Thus, the management can handle the risky situation more efficiently by mitigating losses and balance government security plans (Skipper, 2001). Hence, profitability is an imperative parameter of performance, because it reflects management efficiency in term of asset utilization (Rahman et al., 2012).

In this way, the insurance sector is pivotal for masses as well as for the business venture, because it treats the losses of other sectors and put them in the original position. Additionally, insurance firms provide social and economic benefits by inclining employment rate and reduce fear (Gashaw, 2012). Pervan (2014), completed a study on Macedonian insurance companies and suggested that expense ratio, size of the company, claim ratio, economic growth (GDP), and inflation are significant determinants of the study. Moreover, claims ratio and expense ratio has an inverse association with profitability, however, GDP growth has positive and the inflation rate has a negative influence on profitability.

1- IBMS, The University of Agriculture, Peshawar

2- IQRA National University, Peshawar.
3- IQRA National University, Peshawar, khurshediqbalswati@gmail.com

JISR-MSSE Volume $16 \quad$ Number 2

July-December $2018 \quad 97$ 
However, from last decades Insurance sectors face many challenges such as political instability, terrorism, energy crisis and low purchasing power etc (Ullman, R. H. 1983). As a result, all these exogenous parameters badly influence performance as well as premiums of insurance companies, which are declined by six percent in 2011 from 2010 (BMA Capital, 2011). Numerous academic studies have been documented to identify the main factors of profitability that would be a focal point for the management. The insurance industry is highly competitive and mature, therefore, cost efficiency may be the foremost driver of portability (Greene and Segal, 2004). Thus, Insurance penetration is quite less in Muslims countries such as Indonesia, Turkey, and Pakistan as compared to the global insurance market (Patel, 2004). Most of the studies investigate profitability in term of micro and macro factors in different sectors. However, a scant number of articles have completed in insurance sector of Pakistan, but these studies only consider firm-level determinants of profitability like Hifza Malik(2011), Ahmad et al. (2011), Sumeria and Bilal (2013). Thus, the researchers are confident to fill an important gap to some extent by analyzing prominent Financial and Economic Determinants of Profitability in the insurance sector of Pakistan.

\section{LITERATURE REVIEW}

In this study, the most appropriate literature of micro and macro factors are critically reviewed, these factors influence the performance of the firm in various ways. In addition, the profitability of the firm is influenced by many Firm-specific and Macroeconomic factors. However, these empirical studies give results out of which some are positive, negative or have no relation with profitability and the variables which are influenced by the factors in an opposite way.

Fecheret al. (1993) conducted study on the relative productive performance of 84 life and 243 non-life French insurance companies during the study period from 1984 to 1989. In addition, they concluded that parametric and non-parametric approaches are highly correlated but widely dispersed in the rate of inefficiency across selected companies. As a result, researchers suggest that the aforementioned dispersion can be minimized by controlling variation in scale, ownership, reinsurance, distribution and claims ratio. Greene and Segal, (2004), used a sample of 136 U.S. life insurance companies during the study period of 1995-1998. The researchers suggest that cost inefficiency is significantly associated with earnings in the life insurance sector, but inefficiency is inversely related with profitability proxy like return on equity. Thus, the study concludes that shareholder-owned companies are efficient and profitable that policyholders companies. Ahmed et al. ( 2011), evaluated the determinants of profitability in six life insurance industries of Pakistan during the study period of 2001-2007 by using panel data technique. They explained the firm-level characteristic such as leverage, size, growth, age, liquidity, business risk, and asset tangibility, and finds that leverage, risk, and size are significant parameters of profitability. Conversely, the tangibility of assets, growth, liquidity, and age of the firm are insignificant determinants of life-insurance sector.Malik(2011), examined the determinants of 34 insurance firms of Pakistan over the study period of 2005-2009 by using Return on the asset as a proxy for profitability. He used a regression model for the study, thus size and volume of capital is positive and significant parameters of insurance companies. On the other hand, an inverse relationship is found between profitability and leverage and loss ratio, however, profitability and age have no significant association in the insurance sector. Sumeria and Bilal (2013), evaluated the factors of profitability in 31 insurance companies during the study period of 2006-2011. They used fixed effect model for panel data by concluding that leverage, age and earnings volatility are significantly negative

\begin{tabular}{|c|c|}
\hline 98 July-December 2018 & Volume 16 \\
\hline
\end{tabular}


and size is significant positive determinants of profitability. Conversely, liquidity and growth opportunity is an insignificant factor of profitability in the insurance sector of Pakistan. Mehari and Aemiro (2013), scrutinize firm-level factors of profitability in the insurance sector of Ethopia over the period of 2005-2010. The researcher findings conclude that leverage, size, tangibility are a positive and statistically significant influence on profitability. On the other hand, business risk is inverse but significantly associated with the profitability of the insurance sector. However, the researchers identify that liquidity, the age of the firm and growth are insignificant determinants in the study. Jan et al. (2014), analyze the impact of internal factors on the profitability of six insurance companies in Pakistan during the study period of 2010 to 2013 by using two proxies ROA and ROE. They employ the empirical model by evidencing that Gearing ratio; asset management and NPLs ratio are a significant influence on profitability in both models of profitability. However, Return on equity gives insignificant results of conventional and Islamic insurance companies. Cecila Nicoleta (2014), analyzes firm performance and competitiveness in Romania, he concludes that national competitiveness measures by (GCI) and GDP per capita are positively correlated with performance(ROA). Pervan (2014), completes a study on Macedonia insurance companies by suggesting that expense ratio, size of the company, claim ratio, economic growth (GDP), and inflation are significant determinants of the study. Moreover, claims ratio and expense ratio has an inverse association with profitability, however, GDP growth has positive and the inflation rate has a negative influence on profitability. Rahman, Kakakhel \& Ali(2017) evaluates factors of Islamic and conventional Insurance by finding that (e.g.; size, tangibility, managerial efficiency and economic growth) have a positive and significant relationship. On the other hand, financial leverage and inflation rate are negative but significant factor of performance.

\section{Factors of Profitability}

The dependent and explanatory variables are used in the study and their expected associations are provided in Table 1. In the literature review, most of the research studies have selected the profitability ratio as dependent variable by using proxy of Return on asset (ROA) (Ahmad et al., (2011); Malik (2011); Sumeria and Bilal, (2013); Cecila Nicoleta (2014) Rahman, Kakakhel \& Ali (2017). However, the proxy employ here for profitability is described as net income after tax to total assets of the insurance companies. Thus, the proxy (ROA) measures that are more prominent because it shows both the efficiency and profitability of the firm. 
Table 1

Opertionalization of Variable.

\begin{tabular}{|c|c|c|c|c|}
\hline $\begin{array}{l}\text { Firm Level } \\
\text { variables }\end{array}$ & $\begin{array}{c}\text { Variables } \\
\text { measurements }\end{array}$ & Type of variables & Expected signs & Research \\
\hline Profitability & Net income/total assets & Dependent & - & $\begin{array}{c}\text { Ahmad et al.,(2011); } \\
\text { Malik (2011); } \\
\text { Sumeria and Bilal,(2013) }\end{array}$ \\
\hline Leverage & Total liability to total assets & Independent & - & Ahmed et al. (2011) \\
\hline Liquidity & $\begin{array}{c}\text { Current assets } \\
\text { Current liability }\end{array}$ & Independent & - & $\begin{array}{c}\text { Sumeria and Bilal, 2013, } \\
\text { Rahman, Kakhel \& Ali (2017) }\end{array}$ \\
\hline Size & Natural log total assets & Independent & + & \\
\hline Growth opportunity & $\begin{array}{l}\text { Sale growth to total } \\
\text { asset growth }\end{array}$ & Independent & + & Sumeria and Bilal (2013) \\
\hline Business Risk & $\begin{array}{l}\text { Stand deviation of } \\
\text { operating income/total assets }\end{array}$ & Independent & - & Ahmad et al. (2011) \\
\hline \multicolumn{5}{|l|}{$\begin{array}{l}\text { Macroeconomic } \\
\text { variables }\end{array}$} \\
\hline Inflation rate & Annual inflation rate & Explanatory variable & - & Pervan et al. (2014) \\
\hline GDP rate & $\begin{array}{l}\text { Annual GDP } \\
\text { growth rate }\end{array}$ & Explanatory variable & + & $\begin{array}{c}\text { Pervan et al. (2014) } \\
\text { Rahman, Kakhel \& Ali (2017) }\end{array}$ \\
\hline
\end{tabular}

Source: compiled by researchers based on prior studies

\section{RESEARCH METHODOLOGY}

The study mainly focuses on the investigation of firm-specific and country-level factors that drive corporate performance of Pakistani insurance industry. As a result, a convenient sample of 41 insurance companies (Life, General and Takaful industry) are chosen from the population of 50 insurance companies. The current study also includes takaful industry, which started their operation in 2006. At last, the final sample was composed of strong unbalanced panel data of 41 insurance companies of Pakistan from 2007-2017. The financial data has been extracted from financial statements of the insurance companies, includes Insurance Books, State Bank of Pakistan and Annual reports. However, Economic Data has been collected from the State Bank of Pakistan and the World Bank. The current study is using panel data, which is a mix of both times series and cross-section data. Many econometric techniques are employed for conducting analysis with panel data, but most prominent and widely used techniques are fixed effect, random effect and pooled OLS. Hausman's specification test and Breusch-Pagan Lagrange multiplier (LM) tests are used to find the most appropriate models among the aforementioned models for this study. The significant result of Hausman's specification test supports the fixed effect model between fixed effect and random effect model. However, the insignificant result of Breusch-Pagan Lagrange multiplier (LM) test supports the pooled regression model between random effect and pooled Ordinary Least Square (OLS).

In Fixed effect model, the slope coefficient is constant and intercept varies across the cross-sectional unit in panel. Contrary, in random effects model cross-sectional unit are varies in the model but this model deal cross-sectional unit. Pooled OLS is also known as pooled regression model or constant coefficient model because in this model both intercept and slope are constant. The pooled OLS consider all the companies same with respect to profitability. Equations of Econometric techniques are given below:

100 July-December $2018 \quad$ Volume $16 \quad$ Number $2 \quad$ JISR-MSSE




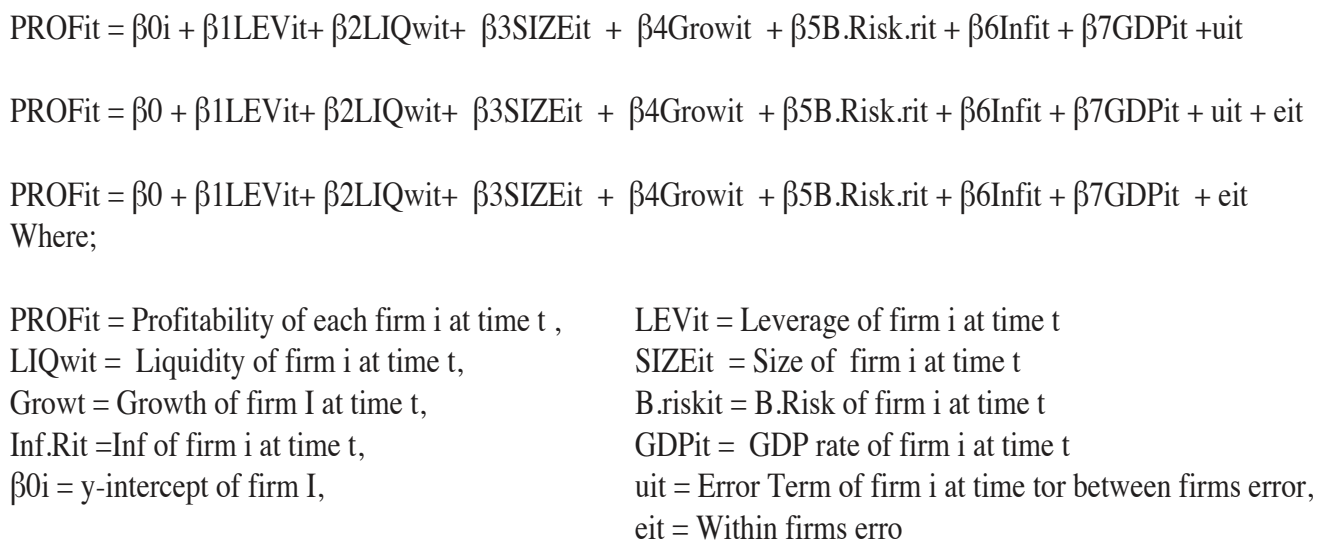

Figure 1 Conceptual Framework.

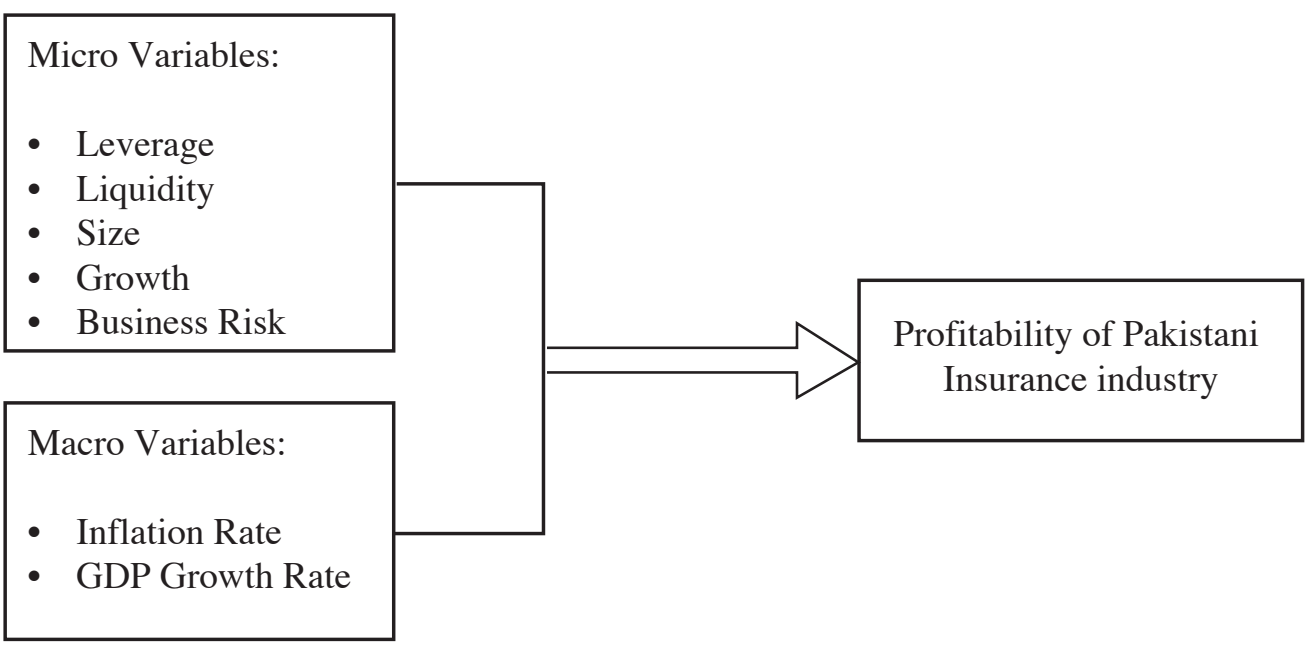

The above diagram displays the insurance specific and country level determinants are explanatory variables and profitability of the firm (ROA) as the dependent variable. According to the authors knowledge, the internal factors such as leverage, liquidity, size, growth and business risk and macroeconomic factors for instance inflation and GDP are the significant determents of Profitability.

\section{EMPIRICAL RESULTS}

This part of the study includes Pearson Correlation matrix and outcomes of Regression models table 2 shows the Pearson's correlation coefficient matrix, however, prior executing the panel data models, it is important to ensure the correlation between explanatory variables. Hence, the results in table 2 verifies that there is no problem of multi-collinearity in the models because the values of the correlation do not go beyond from the cut point 0.6. 


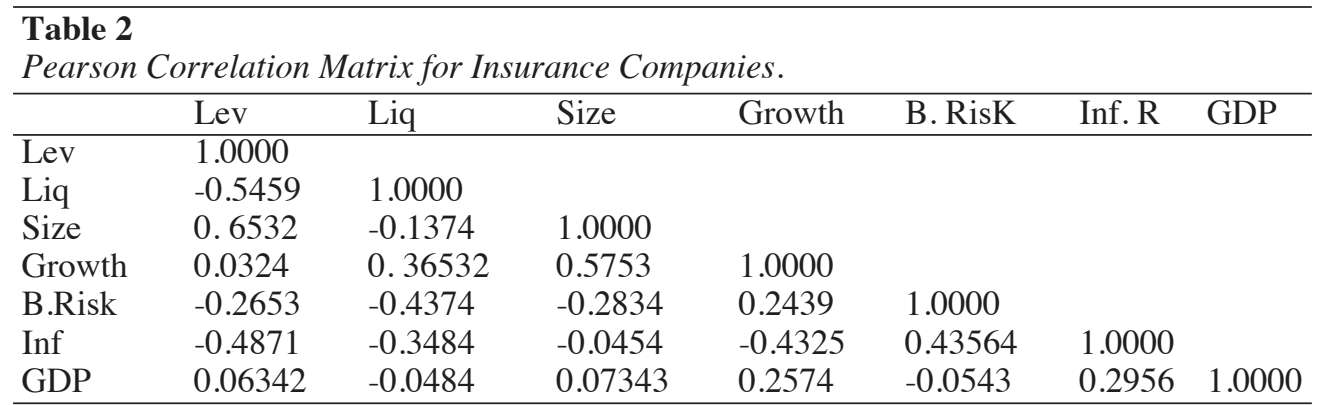

Sources: Stata Output of Stata Software of Annual reports of Insurance companies, State Bank of Pakistan and World Bank

\section{Diagnostic Test}

Test normality Data Shapiro-Wilk test "(P-value is greater than 0.05$)$ shows that the distribution is normal".

Heteroskedasticity Test Breusch-Pagan/Cook-Weisberg test. "The result is found P-value is 0.5923 , which is greater than 0.05 , therefore, this model does not face any heteroskedasticity problem".

Testing for Multicollinearity "Variance Inflation Factor (VIF) and Tolerance (TOL) Value of VIF is less than 10 and tolerance (1/TOL) is less than 1 indicates that the data is free of Multicollinearity".

Model Specification between Fixed effects and Random effects "Hausman specification test The Hausman's specification test presents significant results because the model has the value of $\mathrm{p}=0.0000(\mathrm{P}<0.05)$, then it is more suitable to employ fixed effects model instead of the random effects model".

Model specification between Random effects and

Pooled OLS Breusch-Pagan LaGrange Multiplier (LM) test "The insignificant result (Prob $>$ chi2=0.1241) conforms pooled regression model for the study"

As Hausman's specification test verifies that fixed effect model and Breusch-Pagan Lagrange multiplier (LM) test select pooled OLS model for this study. Table 3 depicts the results of both the pooled regression model and fixed effect model of panel data approaches. The column 3 in table 3 reveals the outcomes of pooled OLS, under this model micro-factor of profitability such as Leverage, size, business risk, and country-level factor for instance Inflation and GDP are significant determinants of profitability. However, liquidity and growth opportunity is insignificant variables of profitability.

On the other hand, fixed effect model from table 3, column five depicts that leverage, business risk, and inflation are negative but significant effect on the profitability of the insurance industry of Pakistan. However, size and GDP are positive and statistically significant influence on profitability. Liquidity and growth insignificantly influence on Return on Assets(profitability). In addition, R-square is 65 percent, which clarifies that independent variables (i.e. leverage, liquidity, size, growth, business risk, inflation, and GDP) explore 65\% variation independent variable like profitability.

102 July-December $2018 \quad$ Volume $16 \quad$ Number $2 \quad$ JISR-MSSE




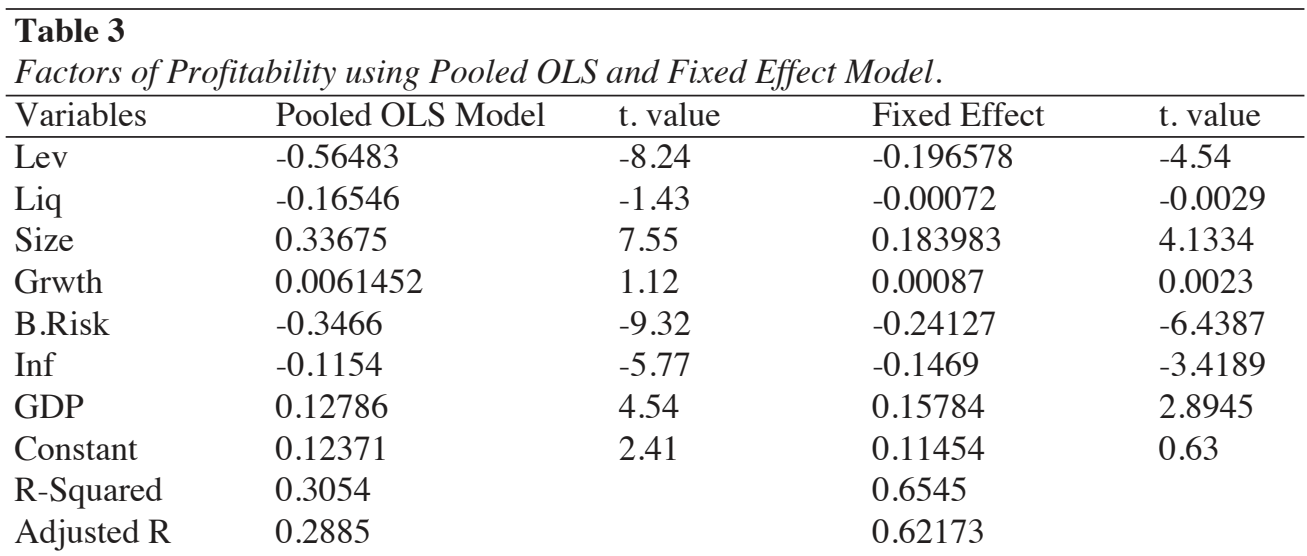

Sources: stata software outcomes from financial statements of insurance companies and World Bank

\section{Discussion and Analysis}

Leverage: The pooled regression model has three significant internal variables and two external variables, which composes leverage, size, business risk, inflation rate, and GDP rate, however, liquidity and growth are insignificant parameters of the study. Debt ratio (leverage) is proved negative and significant determinant of profitability across both models pooled OLS and fixed effect model. These findings are in line with the prior studies completed by Ahmad et al. (2011) in the life insurance sector, Malik (2011) in the insurance industry of 34 companies in 2005-2009; however, Sumeria and Bilal. (2013) in insurance companies of Pakistan. This inverse association shows that if insurance firms incline their debt portion in the capital structure, then the profitability would be declined significantly. Moreover, insurance firms heavily depend on the stock while raising funds from the market, however issuing of stock is another challenge for the top-echelon, due to the unstable nature of Pakistani stock market. Thus, an internal source could be an effective source for insurance sector by optimal utilization of resources.

Liquidity: Liquidity is proved negative but insignificant variable of insurance company's profitability. Furthermore, this association has revealed the greater current ratio of insurance companies resulted in lesser profitability. these outcomes stand in line with the findings of Ahmed et al. (2011); Sumeria and Bilalet al. (2013) Rahman, Kakhel\& Ali(2017) in the insurance sector of Pakistan. Mehari and Aemiro (2013) are also found the insignificant determinant of the Ethiopian insurance sector.

Size: Size of the company has a positive and significant effect on profitability across both regression model (i.e. fixed effect and pooled OLs model). In addition, this relationship has proved that inclined trend of the premiums resulted in higher profitability. The size of the firm could increase the profitability of the firm because most of the firms do not create revenue in the initial stage, but as the size of the firm incline, the portion of the profitability also enhances. This finding supports many research studies such as Mehari and Aemiro(2013) in the Ethiopian insurance sector, Malik (2011), Sumeria and Bilal (2013)and Rahman, Kakhel\& $\operatorname{Ali}(2017)$ in the Pakistani insurance industry.

\begin{tabular}{lll}
\hline JISR-MSSE & Volume 16 & Number 2 \\
\hline
\end{tabular}


Growth: Growth factor has a direct but not significant association with profitability in ordinary least square model and fixed effect model, this proves that firms' incline their premiums and grow continuously, but this growth could not generate any results to the insurance sector of Pakistan. Because of numbers of systematic and controllable factors that create hindrances in this way, for instance, high inflation rate, poverty, low GDP and high operation cost. This result is in line with Ahmed et al. (2011), Mehari and Aemiro (2013), Sumeria and Bilal (2013) and Rahman, Kakhel\& Ali(2017) in the insurance sector.

Business Risk: Business risk is negative but significantly influence on profitability across both regression models. This means that high risk in Pakistan due to war and terror and energy crisis would significantly reduce the profitability of the insurance companies. The high history and stable firm are not even generating a profit because of the current challenges faced by Pakistan. This finding is same with results of Sumeria and Bilal (2013) in the insurance industry of Pakistan.

Inflation Rate: Inflation rate is an inverse but significant influence on profitability across both panel data models of insurance sector of Pakistan. This result shows that a high inflation rate can decline the purchasing power of the masses and these people cannot save money in the capital market. In an inflationary economy, peoples are face hurdles to meet their basic needs. Pervanet al. (2014) also finds a negative and significant impact of inflation with profitability in Macedonia insurance companies.

GDP Rate: GDP rate has proved positive and significantly affect on the profitability of insurance sector of Pakistan. This means that when people are become prosper they go for investment in a capital instrument. Insurance policies are also a part of capital instruments, when per capita income inclines, surplus money could be saved in the insurance sector. These findings are congruent with the study of Pervanet al. (2014).

\section{CONCLUSION}

This study is designed to explain the main factors of profitability in the insurance industry of Pakistan over the study period from 2007 to 2017. A panel data of 41 insurance companies of life, non-life, and takaful companies are chosen for this study. Hausman's specification and Breusch-Pagan Lagrange multiplier (LM) tests have approved most appropriate model (i.e. fixed effect and pooled OLS) for the study. In addition, the results of fixed effect and pooled OLS reveal that leverage, business risk, and inflation rate are negative but significantly influence the profitability of the insurance sector of Pakistan. However, size and GDP are positive and significantly affect profitability. At last, Liquidity and growth are insignificant parameters of profitability of the study. The upcoming studies must cover a complete financial sector of Pakistan, along with firm level and macroeconomic factors.

\section{REFERENCES}

Abate, G. (2012). Factors Affecting Profitability of Insurance Companies in Ethiopia: Panel Evidence (Doctoral dissertation, aau).

Ahmed, N., Ahmed, A., \&Usman, A. (2011). Determinants of Performance: A Case of Life Insurance Sector of Pakistan. International Research Journal of Finance and Economics, (61), 123-128. 
BMA Capital. (2011). Strategy Outlook 2011: Pakistan Rising ( 1-64). Pakistan: BMA Capita.

CecilaNicoletaJercut (Anis) (2014). Competitiveness and firms performance on emerging countries. The Romanian case, proceedings of MAC-EMM.

Fecher, F., Kessler, D., Perelman, S., \&Pestieau, P. (1993). Productive performance of the French insurance industry. Journal of Productivity Analysis, 4(1-2), 77-93.

Gitman, L. J. (2007). Principles of Managerial Finance (12th ed.): Addison Wesley.

Greene, W. H., \& Segal, D. (2004).Profitability and efficiency in the US life insurance industry. Journal of Productivity Analysis, 21(3), 229-247.

Jan, S., Iqbal, K., \&urRahman, S. (2014). Determinants of Profitability of Islamic and conventional Insurance Companies in Pakistan: an Internal Evaluation. Abasyn University Journal of Social Sciences, 7(1).

Malik, H. (2011). Determinants of insurance companies profitability: An analysis of insurance sector of Pakistan. Academic Research International,1(3), 315.

Mehari, D., \&Aemiro, T. (2013).Firm Specific Factors that Determine Insurance Companies Performance in Ethiopia. European Scientific Journal, 9(10).

Murungi, D.U(2014). Relation between Macroeconomic variables and Financial Performance of Insurance Company in Kenya.

Ocampo, J. A. (2018). International Asymmetries and the Design of the International Financial System 1. In Critical Issues in International Financial Reform (pp. 45-74). Routledge.

Patel, S. (2004).Takaful and poverty alleviation. The International Cooperative and Mutual.

Pervan, M., Poposki, K., \& Ćurak, M. (2014). How Well Insurance Companies in Macedonia Perform?. Researches in Applied Economics and Management, 1.

Rahman, S. U., Kakakhel, S. J., \& Ali, L. (2017). Financial and Economic Factors that influence Profitability of Insurance Sector in Pakistan.

Rahman, S. U., Jan, F., Iqbal, K., \& Ali, Z. (2012). Parameters of conventional and Islamic Banks profitability: Evaluation of internal Analysis. Research Journal of Finance and Accounting, 11-18.

Skipper, H. D., \& Barfield, C. E. (2001). Insurance in the general agreement on trade in services. American Enterprise Institute.

Sumaira, B., \&Amjad, T. (2013). Determinants of profitability panel data evidence from insurance sector of Pakistan. Finance Management A, 57, 14377-14382.

Ullman, R. H. (1983). Redefining security. International Security, 8(1), 129-153.

Skipper, H. D. (1997). Foreign insurers in emerging markets: issues and concerns (No. 1). Washington, DC: International Insurance Foundation. 
